\title{
Building A Beyond Corporate Social Responsibility Conceptual Model Based on Harmonic Cosmological Philosophy and Priest Heliocentric Al Ghazali
}

\author{
Ade Manggala Hardianto ${ }^{1 *}$, Basuki $^{2 *}$ Bonnie Soeherman ${ }^{3 *}$
}

\author{
1,2 Airlangga University of Surabaya \\ ${ }^{3}$ University of Surabaya \\ *Corresponding authors. Email: ade.manggala.hardianto-2016@feb.unair.ac.id. \\ basuki@feb.unair.ac.id., Bonnie_S@staff.ubaya.ac.id.
}

\begin{abstract}
This research aims to build a conceptual model of Beyond Corporate Social Responsibility (BCSR) based on Imam $\mathrm{Al}$ Ghazali's philosophy of cosmology, particularly on the concepts of harmony and heliocentric. Finally, this research seeks to restore CSR to the level of efforts to create harmony in life, not just regulations or mere imagery. This research used an interpretive paradigm by prioritizing qualitative data in building the BCSR construct as referred to in the research objectives. Literature studies are in depth to explore the basic essence of cosmology from the perspective of Imam Al Ghazali.

This research produces a conceptual model construct of BCSR that looks from the perspective of the harmony and heliocentric cosmology of Imam Al Ghazali. Researchers get a green enlightenment that CSR should be "created" from a goal worthy of the noble purpose of the process of creating the universe and universe by Allah SWT. CSR should be built from the spirit to create a new, better order, improve the welfare and quality of life of other humans, other creatures, and the environment, even beyond all this, to glorify Allah. At the next level, CSR must be able to maintain the harmony of the company with the environment in the company as a small universe and its harmony with the external environment or large universe. In the end, the essence of all essence is that all forms of CSR activities must be based on high spiritual values as contained in the Al Quran. A finding called Beyond Corporate Social Responsibility

This research tries to explore the concept of Imam Al Ghazali's cosmology in depth and make it the basis for building a holistic CSR construct or what is called BCSR. The building of universal harmony and placing the Koran as the basis of all corporate movements. The main limitation of this study is the lack of literature on Al Ghazali's philosophy that is relevant to modern business concepts, especially CSR. Also, the results of this study are still in the form of propositions that need to be implemented and measured carefully.
\end{abstract}

Keywords: CSR, CSV, Beyond CSR, heliocentric, cosmology, Imam Al Ghazali 


\section{INTRODUCTION}

Corporate responsibility activities are well known throughout the world because they are sponsored by governments and international organizations. In general, the definition of CSR describes the social voluntary (voluntary social), and environmental aspects of the company. Another definition of CSR describes business commitments such as ethical behavior and the contribution of economic progress, improving the quality of life of workers and their families. Previous researchers have analyzed criticism of CSR. First, CSR activities are a violation of shareholder rights. The company's goals are to create profit, institutional governance, sovereignty, discipline, involve the state government and companies do not allocate money if they do not provide wealth to the company (Galant, 2017). Second, CSR activities do not pay attention to the differences between large companies and small and medium enterprises, so an explanation is needed to emphasize the behavior of small and medium enterprises with CSR activities such as a corporate perspective social (social) and responsibility (Jenkins, 2004). . Third, corporate responsibility activities to society reflect neoliberalism, and CSR has explicitly turned into a proportion of economic value or Economic Value Proportion (Vallentin \& Murillo, 2019).

CSV arises due to friction and tension between business problems and social problems, and the intersection of corporate power and social impact includes resources, expertise, and management to create favorable social conditions rather than philanthropic institutions and organizations. Porter and Kramer claim as quoted by Vallentin \& Murillo (2019) that corporate success and social welfare can provide opportunities for corporate success and social progress. The framework of the Creation of Shared Value (CSV) reflects policies and operating practices that enhance the competitiveness of companies while advancing economic and social conditions in the communities in which companies operate but Creation of Shared Value (CSV) has rational limitations. The rational limitation of Creation of
Shared Value (CSV) is the practical application of $\mathrm{CSV}$ as a framework that identifies a series of goals and the best way to achieve these goals or win-win situations, and a conceptual framework through moral integration in the cognitive processes of strategic management (Lee, 2019) and Non-based framework.

The Western Domain is like a condition credibility and practice in developing countries (Voltan et al., 2017). Based on the study above, the researcher asked a question? how about practical conceptual designs to achieve win-win solutions in the strategic management process?

\section{LITERATURE REVIEW}

\subsection{The philosophy of Imam al Ghazali}

The philosophy of Imam al Ghazali has been researched as new knowledge, such as conceptual business ethics as a new foundation and practical implications of a dynamic work ethic both in theory and practice (Sidani \& Ariss, 2015) and Imam al Ghazali is more than just an interpreter and transmitter of Greek thought ( Ghazanfar, 2000). Imam al Ghazali's views provide a new paradigm, especially in the Muslim community. There are 2 (two) reasons why Imam al Ghazali's philosophy is used, namely 1) the work of Imam al Ghazali has influenced many people as quoted by Sidani \& Ariss (2015), including David Hume and St Thomas Aquinas. 2) Imam al Ghazali's views include spiritual and new research initiatives in the Muslim community.

The essence of Imam al Ghazali's philosophy in practice includes 4 (four) aspects (Sidani \& Ariss, 2015), among others, 1) knowledge before action, namely knowledge that is relevant to support action. Knowledge is mandatory for every Muslim and knowledge can be used as a basis for right actions or can avoid sinning, 2) Prioritizing virtue. Imam al Ghazali does not prohibit a person from seeking profit but maximizing profit is not a virtue sought. Ghazali's view contradicts modern economic theory which tends to accumulate wealth and good behavior only to fulfill necessities of life or simplicity. 3) Fairness and care for stakeholders (Justice and Care for 
Stakeholders). The concept of justice in question is to take fair action against Allah SWT and humans. This situation is in line with Orman's (2018) statement that fair action includes divine justice and human justice. Divine justice describes the justice of Allah SWT to the entire universe including humans, and human justice describes justice in oneself and justice to the social or the environment, 4) Doing good to the environment. The act of doing good to the environment can create harmonious relationships, for example, avoiding excessive profits, tolerating the difficulties of others, and carrying out social responsibility or CSR.

\subsection{Cosmological Knowledge and Practice}

Cosmology reflects the nature of the universe with a larger scale of observation and explains events to date (Ellis, 2001). These extraordinary events have a wealth of knowledge and are used by philosophers looking for the meaning behind events over the past 50 years. In the last decade, the cosmological phenomenon of the universe has developed that billions of universes are also there (Ellis, 2011). The Hidden Reality as quoted by (Ellis, 2011) talks about the super Copernican. In this view, it is not only the planet Earth among the cosmic scales of the universe that are innumerable and each of them performs independently. Astronomers can see up to a distance of about 42 billion years and a cosmic visual horizon that doesn't stop evolving.

The cosmological phenomenon leads to understanding who did it (Shermer, 2012). This understanding is understood logically if Allah SWT created it then no other creator is needed. Thus the nature requires more exploration of where things come from. This situation is in line with the statements of Niels Bohr and Danish Physicist quoted by (Horgan, 2001) "the opposite of a correct statement is false a statement. But the opposite of profound truth may well be another profound truth". In general, the concept of cosmology in practice reflects the internal interactions of organizations and improvisations to maintain organizational existence such as the cosmology of individuals, teams, organizations, and communities (Orton \& O'Grady, 2016).
First, cosmology at the individual level actively interacts with the routine activities of the organization mechanisms and procedures. Individual cosmology changes when individuals face drastic changes beyond their means and have an impact on individual performance and even changes can cause individual frustration, for example, individuals can work well in an unambiguous and orderly environment. A stable work environment can regulate the interaction process between individuals into an integrated unit, conversely, if the work environment is ambiguous it can cause damage to individual interactions.

Second, Team cosmology is based on mutual trust between individuals to overcome obstacles or obstacles. A sense of mutual trust can bring individual actions into action organized team, let's address the issue of natural disasters in the team's action.

Third, cosmology at the organizational level is like the five senses capable of capturing external information, spreading and interpreting the meaning of information. The elasticity of an organization's actions on the environment has an impact on the resilience of the organization and its resource allocation strategy.

Fourth, community cosmology includes all elements or organizational elements in a particular environment. The concept of societal cosmology is broader in scope and multi-element interaction. Community cosmology reflects the attitude of all elements of society to pay attention to environmental change and take action for example, climate change caused by drought and reduced water discharge causes villagers or cities to experience water distress must try to find common solutions to overcome water shortages that hit. villagers or townspeople.

Conflict can occur when there is a conflict between religious values or beliefs and the work environment (Exline \& Bright, 2011). For example, if an organizational leader establishes a spiritual practice program in the workplace, it may be possible to partially accept or reject the organization's program because spiritual beliefs cannot be enforced and the spirituality of individuals or communities cannot be compared. Spiritual has lost the existence of the meaning of spiritual values, and to recognize it with 
new meanings such as motivation and commitment (Drive, 2007).

\section{RESEARCH METHOD}

This research is a narrative research, finding detailed data from certain cases, making facts understandable but not generalizable or not emphasizing predictions (Morissan, 2019). Literature sources come from previous research studies and the concept of Imam al Ghazali's cosmological philosophy.

\section{RESULTS AND DISCUSSION}

Imam Al-Ghazali has a special cosmological view. The term cosmology comes from understanding the relationship between what is usually believed to be a cause and an unnecessary effect. This sentence is not meant to negate the existence of a cause and effect connection but is considered a distinct (if it never existed, never different) relationship. The relationship between cause and effect depends. For example, the API energy does not cause the cotton to burn (alternative / maybe other cause). Causality is necessary when there is something else. The term something else is "there is wanting" which shows its existence.

Al Ghazali did not reject the term secondary causality (power created to act). Al Ghazali's view is not on how God creates a relationship between cause and effect, but that two events (cause and effect) can be identified in knowledge. Cause and effect are not separated as two events that regularly appear between them. Practically, there needs to be an inclusive understanding (hidden), including knowledge, intention, and action

First, the knowledge of the creation of the universe human life. For example, the creation of the solar system consists of the sun, planets, and satellites which are interconnected. Relational knowledge can change along with the understanding and perceived benefits of this relationship (Ledingham, 2014). The relational view is in line with the view of a collective partnership that encourages more effective environmental policy principles consisting of the distribution of resources, the role of the community, and companies in partnership with the community (Backstrand, 2010).

Second, the creation of the universe due to desire of Allah SWT to be achieved (Griffel, 2009). Volunteerism considers the capabilities possessed by partners such as money, skills, motivation and intention, the implementation process, the implementation of activities that have been carried out, and the evaluation of the direct or indirect impact on development (Kolk, Tulder, \& Kostwnder, 2008).

Third, the act of creation reflects the relationship between the creator and his creatures. Relationship or relational characteristics reflect collaborative action, accountability partnerships between perceived needs and shared desires (Forrer, Kee, Newcomer, \& Boyer, 2007). There are 4 (four) factors in building partnerships 1) building trust 2) a commitment to partnership initiatives 3) clear roles that must be articulated orally and in writing 4) involving partners from community elements (Mcneish, Rigg, Tran, \& Hodges, 2019).

Practically, Imam al Ghazali's philosophy of cosmology can build a foundation of Corporate Social Responsibility (CSR) for the welfare of society, including 1)

Knowledge builds collective partnerships to encourage the generosity of the people, 2) Voluntary action encourages a willingness to participate or abilities such as money, skills, motivation and intention, the implementation process, and 3) partnership accountability consists of the collective ability of partners to build good relationships.

\subsection{The Essence of Imam al Ghazali's Cosmology}

The main thoughts of Imam al-Ghazali based on the knowledge of the act of creation (secondary causality) and the basic foundations of cosmological knowledge were analyzed to validate Allah SWT, namely (1) Science of Kalam or the science of rational logic which explains natural events and philosophy sourced from the Qur'an and Hadith 2) Metaphysics that explains the existence of nature, and why nature was 
created (3) Philosophy that explains science and analysis - analysis based on the Qur'an.

The essence of secondary causality becomes science, among others; first, the creation of the universe provides knowledge of natural and heliocentric harmonization (Woolfson, 2000). First, the accountability of partnerships or the ability of partners to manage resources such as money, skills, motivation, and intentions (Kolk, Tulder, \& Kostwnder, 2008). Second, Divine voluntary action provides knowledge of awareness and volunteerism, the Divine Irada reflects corporate awareness and volunteerism towards the environment (Frederick, 1960). Third, the interactions between the sun, planets, and satellites provide knowledge of the balance between individuals, teams, and groups. Interactions reflect the balance between the sustainability of companies doing business activities and the welfare of the community (Eid \& Sabella, 2014).

The axiology of corporate responsibility to society has not yet covered the philosophy of Imam al Ghazali, namely social justice which prioritizes the needs of human life that must be protected or Maqasid Al Shariah (Orman, 2018), among others; 1) protection of religion, 2) protection of life, 3) intellectual protection, 4) protection of heredity and 5) protection of property and assets. In this sense, justice is the minimum standard of behavior in human relations and the virtue of acting to benefit others. Practically, Imam al Ghazali's philosophy regarding the necessities of human life includes minimum standards of behavior in human relations (justice) and benefits others (virtue).

\subsection{BCSR Relationship and Environment}

The interaction between BCSR and the environment is important to create harmony.

The conceptual BCSR creates a harmonious and heliocentric environment shown in the broad aspect and balance between investors, local government, community, technology, unemployment and and green environment.
The CSR environment and investors become the spirit or motivation of the company to pay attention to and overcome social problems in society such as the level of welfare, unemployment, and poverty as a result of the income gap. Spirit or motivation used as a competitive advantage, strategy, and business benefits (Anderson \& Bieniaszewska, 2005). Information about competitive advantage in the digital era can be easily reached, such as news, mass media, newspapers which are used as an important source of presenting and enhancing images public companies and investors in the other (Magee, 2018).

The CSR environment and the government are the main focus of the government, especially increasing social development in both local and city government environments. Local government programs covering social activities are not fully funded by the APBD / APBN. This action also aims to strengthen weak institutions (Amaeshi et al., 2015), and create institutional governance, sovereignty, and discipline and involve the State government (Galant, 2017). The role of the government, both regional and city, in implementing CSR activities provides comfort for investors.

CSR relations with the community are the main focus of community problems. Accountability is contradictory even though several institutions claim to have accountability (Steets, 2004) and partnership participation involves various institutional sectors such as government, companies and social organizations (Backstrand, 2010).

Non-governmental organizations are formed by local governments involving various elements including companies, NGOs, academics, and community leaders. Multisectoral partnerships fulfill at least a four-stage process in the policy cycle. First, knowledge and partnership awareness. Each partner must have sufficient knowledge of the objectives of this partnership and an awareness of the consequences of being involved in the partnership. Second, partnership policies. Partners should be involved in policies or strategic steps to achieve partnership goals. Third, policy implementation. Partners carry out policy outcomes consistently and transparently. Fourth, policy evaluation through official forums which are held at least once a year and annual 
reporting. Four, CSR relationship with technology creates environmental friendliness such as air pollution, drinking water pollution, housing, and public health. Environmentally friendly technology can increase a company's reputation and value for investors.

The relationship between technology and the environment is based on the concept of Corporate Social Responsibility or CSR which began to emerge before 1950, where activists saw the source of poverty, social and slum problems due to companies (Carroll, 2009). Although the practice of CSR in each country is different, such as CSR as a tradition, philanthropy, or charity. In essence, management has the main function of balancing stakeholders and society, the image and reputation of the company, and technology that can damage the environment and community traditions (Frederick, 1960).

Green environment can be defined as a reciprocal relationship between the orientation of investors, local governments, non-governmental organizations, and technology. A green environment is needed when the practice of Corporate Social Responsibility or what is called CSR has an impact on the relationship between the company and its environment and when the trust is lost, it is difficult for companies to communicate CSR with stakeholders (Lock \& Schulz-Knappe, 2018).

This communication vulnerability results in the absence of CSR activities and has a broad impact on social development for the welfare of the community, protection of life, rights to earn income, and company comfort. A Green environment can synergize and develop programs that are only charity (charity), and generosity (philanthropy), for example, partnership accountability. Partnership accountability is the ability of partners to manage resources such as money, skills, motivation and intentions (Kolk et al.,2008).

This partnership involves various elements such as government, companies, and non-governmental organizations that are endorsed by local governments. The three elements together can strengthen the basic foundations of social development, among others; 1) elements of local government have regulatory powers as the legal umbrella covering the legality and legitimacy of CSR activities, 2) elements of the company have practical knowledge and money to carry out CSR activities, and 3) elements of nongovernmental organizations have detailed knowledge of community conditions. The Corporate Social Responsibility Partnership is a process to produce a social partnership model and develop alternative activities (Wadham, 2009).

The partnership framework is dynamic as a relationship that tends to evolve and change over time as a result of socio-political and ethical interactions. A good fit and integration between the three dimensions of partners are expected to result inequality, trust, and commitment, which in turn are seen as the main drivers for the sustainability of the partnership.

\section{CONCLUSIONS}

Natural and heliocentric harmonization reflects knowledge from the creation of the universe and the foundation of CSR to maintain good relations between stakeholders such as investors, government, customers, and communities. This knowledge is based on the meaning behind the creation of the universe which reflects accountability for partnerships, volunteerism, interaction, and community welfare.

The BSCR is a new concept from the weaknesses of the CSR and CSV concepts. The essence of the BSCR has an impact on the relationship with the environment, among others; 1) a CSR environment with investors that reflects the spirit and spirituality of the company carrying out CSR activities, 2) a CSR environment to strengthen weak institutions, creating institutional governance, sovereignty and discipline, and involving the state government, 3) CSR environment with the community through the involvement of non-governmental organizations that participate in CSR activities, 4) Environmental CSR with technology creates friendliness to the environment such as air pollution, drinking water pollution, housing, and public health. Environmentally friendly technology can increase the company's reputation and value for investors, 5) green environment or a reciprocal relationship between investor orientation, government, institutions non- 
government and technology as well as minimizing the loss of company trust in the welfare of society.

\section{ACKNOWLEDGMENT}

The authors wish to thank the Indonesian Endowment Fund for Education (LPDP) who has provided support so that the writing of this article can be completed properly on time and supporting full funding for an author.

\section{REFERENCES}

[1]. Amaeshi, K., Adegbite, E., Ogbechie, C., Idemudia, U., Anderson, K., Kan, S., Issa, M., \& Anakwue, O. I. J. (2015). Corporate Social Responsibility in SMEs : A Shift from Philanthropy to Institutional Works? J Bus Ethics. https://doi.org/10.1007/s10551-0152633-1

[2]. Anderson, C. L., \& Bieniaszewska, R. L. (2005). Expansion into New Territories. Corporate Social Responsibility and Environmental Management, 9, 1-9.

[3]. Bäckstrand, K. (2010). The promise of new modes of environmental governance. European Environment, 16, 290-306. https://doi.org/10.1002/eet.425

[4]. Carroll, A. B. (2009). A History of Corporate Social Responsibility: Concepts and Practices (A. Crane, D. Matten, A. McWilliams, J. Moon, \& D. S. Siegel (eds.); Issue February). Oxford Handbooks Online A.

https://doi.org/10.1093/oxfordhb/978019921 1593.003.0002

[5]. Drive, M. (2007). A “ Spiritual Turn " in Organizational Studies : Meaning Making or Meaningless? Journal of Managemen, Spirituality \& Religion, 4(1), 56-86. https://doi.org/10.1080/14766080709518646

[6]. Eid, N. L., \& Sabella, A. R. (2014). A fresh approach to corporate social responsibility (CSR): Partnerships between businesses and non-profit sectors. Corporate Governance (Bingley), 14(3), 352-362. https://doi.org/10.1108/CG-01-2013-0011.

[7]. Ellis, G. F. R. (2001). From bang to eternity (pp. 1-3).

[8]. Ellis, G. F. R. (2011). Cosmology: Does the multiverse really exist? Scientific American, 305(2), 18-23. https://doi.org/10.1038/scientificamerican08 11-38.

[9]. Exline, J. J., \& Bright, D. S. (2011).
Spirituality \& Spiritual and religious struggles in the workplace. Journal of Managemen, Spirituality \& Religion, 8(2), 123142.

https://doi.org/10.1080/14766086.2011.5826 84.

[10]. Forrer, J., Kee, james E., Newcomer, K. E., \& Boyer, E. (2007). Public-Private Partnerships and the Public Accountability Question. Public Administration Review.

[11]. Frederick, W. C. (1960). The Growing Concern Over Business Responsibility. California Management Review, 2, 54-61.

[12]. Galant, M. (2017). the Stakeholders Theory As a Starting Point for the Critique of Corporate Social Responsibility. Social Responsibility of Organization, 464, 31-42. https://doi.org/10.15611/pn.2017.464.03.

[13]. Ghazanfar, S. . (2000). The Economic Thought of Abu Hamid AlGhazali and St. Thomas Aquinas: Some Comparative Parallels and Links. History of Political Economy, 32-34.

[14]. Griffel, F. (2009). Al-Ghazali's Philosophical Theology (1st ed.). Oxford university press.

[15]. Horgan, J. (2001). Cosmos, God and Us (pp. 1-2).

[16]. Jenkins, H. (2004). A Critique of Conventional CSR Theory: An SME Perspective. Journal of General Management, 29(4), 37-57. https://doi.org/10.1177/03063070040290040 3

[17]. Kolk, A., Tulder, R. Van, \& Kostwnder, E. (2008). Business And Partnerships For Development. European Management JournalManagement Journal, 26(4), 2626-3273.

[18]. Ledingham, J. A. (2014). Explicating Relationship Management as a General Theory of Public Relations. Journal of Public Relations Research ISSN:, 15(2), 181-198.

https://doi.org/10.1207/S1532754XJPRR15 02

[19]. Lee, J. (2019). The limits of consequential reasoning in shared value creation. Competitiveness Review: An International Business Journal, 29(1), 2638. https://doi.org/10.1108/CR-08-20160049.

[20]. Lock, I., \& Schulz-Knappe, C. (2018). Credible corporate social 
responsibility (CSR) communication predicts legitimacy. Corporate Communications: An International Journal, CCIJ-07-2018-0071. https://doi.org/10.1108/CCIJ-07-2018-0071.

[21]. Magee, R. G. (2018). Environmental worldview beliefs and CSR advertising. Social Responsibility Journal, SRJ-11-2017-0229. https://doi.org/10.1108/SRJ-11-2017-0229.

[22]. Mcneish, R., Rigg, K. K., Tran, Q., \& Hodges, S. (2019). Community-based behavioral health interventions: Developing strong community partnerships. Evaluation and Program Planning, 73, 111-115. https://doi.org/10.1016/j.evalprogplan.2018. 12.005 .

[23]. Morissan. (2019). Riset Kualitatif (Suraya, F. Hamid, \& E. Bassar (eds.); 1st ed.). Prenadamedia Group.

[24]. Orman, S. (2018). on Justice and Social Justice. Turkish Journal of Islamic Economic, 5(2), 1-68. https://doi.org/10.26414/m020

[25]. Orton, J. D., \& O'Grady, K. A. (2016). Cosmology episodes: a reconceptualization. Journal of Management Spirituality \& Religion. https://doi.org/10.1080/14766086.2016.1159 $975 \mathrm{X}$

[26]. Shermer, M. (2012). Much ado about nothing. Scientific American, 306(5), 72.

https://doi.org/10.1038/scientificamerican05
$12-86$.

[27]. Sidani, Y., \& Ariss, A. Al. (2015). New Conceptual Foundations for Islamic Business Ethics : The Contributions of AbuHamid Al-Ghazali. J Bus Ethics, 847-857. https://doi.org/10.1007/s10551-014-2136-5.

[28]. Steets, J. (2004). Developing a Framework: Concept and research priority for partnership accountability. GPPI Research Paper Series, 1, 2-27.

[29]. Vallentin, S., \& Murillo, D. (2019). CSR and the neoliberal imagination. In Ethical Economy (Vol. 57). Springer International Publishing. https://doi.org/10.1007/978-3-030-154073_2.

[30]. Voltan, A., Hervieux, C., \& Mills, A. (2017). Examining the win-win proposition of shared value across contexts: Implications for future application. Business Ethics, 26(4), 347-368. https://doi.org/10.1111/beer.12159.

[31]. Wadham, H. (2009). Talking across boundaries : Business and NGO perspectives on CSR, sustainable development and partnership. Corporate Citizenship (JCC), 34, 57-68.

[32]. Woolfson, M. (2000). The origin and evolution of the solar system. Astronomy and Geophysics, 41(February). https://doi.org/10.1046/j.14684004.2000.00012.x. 